\title{
THE POTENTIAL OF AN ASPERGILLUS FUMIGATUS BRAZILIAN STRAIN TO PRODUCE ANTIMICROBIAL SECONDARY METABOLITES
}

\author{
Niege Araçari Jacometti Cardoso Furtado ${ }^{1,2}$; Maria José Vieira Fonseca ${ }^{1}$; Jairo Kenupp Bastos ${ }^{1 *}$ \\ ${ }^{1}$ Faculdade de Ciências Farmacêuticas de Ribeirão Preto, Universidade de São Paulo, Ribeirão Preto, SP, Brasil; ${ }^{2}$ Núcleo de \\ Pesquisa em Ciências Exatas e Tecnológicas, Universidade de Franca, Franca, SP, Brasil
}

Submitted: August 04, 2005; Approved: November 16, 2005

\begin{abstract}
During the course of screening for biologically leading active natural products from fungi, a strain of Aspergillus fumigatus was assessed for antimicrobial activity production. Four parameters consisting of medium culture, $\mathrm{pH}$, temperature and time of fermentation were investigated. The extracts from the fungus cultures displayed different TLC profiles and produced, at least, one inhibition zone in the bioautography assays. Overlapping inhibition zones in the range of Rf 0.09 to 0.65 against Kocuria rhizophila were detected in the bioautography assay of the chloroform extract obtained from Jackson's medium culture, initial pH of 6.0 and incubation at $40^{\circ} \mathrm{C}$ for 144 hours. However, the obtained extracts by developing the fungus culture in Vogel's medium furnished the smallest number of active compounds. The obtained chromatographic profiles of the extracts from the fungus cultures by high performance liquid chromatography with photodiode array detector were distinctive, allowing to infer that $A$. fumigatus secondary metabolites production could be affected by modifying any of the undertaken parameters. It should be pointed out that a remarkable difference among HPLC profiles was observed by using different media culture.
\end{abstract}

Key words: antimicrobial activity, Aspergillus fumigatus, bioautography, fermentation conditions

\section{INTRODUCTION}

Natural products from microbial or plant origin have played and still play an invaluable role in drug discovery, which counts for more than $30 \%$ of worldwide human pharmaceutical sales (16). Moreover, natural products and their derivatives, excluding biologics, constitute about $50 \%$ of the approved drugs over the period 1981-2002 (13). Fungi have proved to be capable of biosynthesizing secondary metabolites bearing conspicuous structural diversity, which could be further enlarged by structure modification. Among 20 of the most commonly prescribed medications, six are from fungal origin (3).

Aspergillus fumigatus strains are widely distributed in nature and have an essential role in recycling carbon and nitrogen. This filamentous fungus has become an opportunistic airborne pathogen affecting immunocompromised patients (12).
Otherwise, strains of A. fumigatus have been reported to be producers of metabolites with broad range of biological activities $(2,17)$. A. fumigatus looks taxonomically homogeneous in terms of morphology, but the intraspecies variability at the genomic level is very high (4). Symoens et al. (18) reported the high genetic polymorphism of A. fumigatus isolates and Varga and Tóth (20) described a general overview of the techniques used for the examination of the genetic variability of $A$. fumigatus and suggested that recombination played an important role in A. fumigatus populations.

Secondary metabolites are synthesized by a large variety of pathways and both genetically distinct producing strains and different environmental conditions could affect its production. Fermentation parameters such as time, temperature, $\mathrm{pH}$ and nutrients can be modified to expand the range of the produced secondary metabolites (14). Therefore, the aim of the present

*Corresponding Author. Mailing address: Departamento de Ciências Farmacêuticas, Faculdade de Ciências Farmacêuticas de Ribeirão Preto, Universidade de São Paulo, Av. do Café s/n. 14040-903, Ribeirão Preto, SP, Brasil. Tel: (+5516) 602-4162. Fax: (+ 5516) 633-1941. E-mail: jkbastos@fcfrp.usp.br 
study was to evaluate the ability of a Brazilian strain of the fungus Aspergillus fumigatus to produce antimicrobial activity in different culture conditions. The detection of antimicrobial activity may indicate a broad range of bioactivity, such as antitumor and antiparasitic (5).

\section{MATERIALS AND METHODS}

\section{Microorganisms}

Aspergillus fumigatus was isolated from a soil sample collected in Pantanal - MS, Brazil and was identified by the "Fundação Tropical de Pesquisas e Tecnologia André Tosello", Campinas, SP, Brazil. The microorganism is stored as a conidial suspension on silica gel (6-12 mesh, grade 40, desiccant activated) at $4^{\circ} \mathrm{C}$. The strain of Kocuria rhizophila ATCC 9341 used for antimicrobial evaluation was acquired from the American Type Culture Collection.

\section{Metabolites production}

A two-step culture was performed for antimicrobial activity production, consisting of an initial inoculum of a suspension of $4 \times 10^{6}$ conidia/mL. The fungus was first grown at $40^{\circ} \mathrm{C}$ with shaking (120 rpm) for 24 hours in seed medium (10). The resulting mycelia were harvested, rinsed and transferred to different media: I) modified Jackson's medium consisted of glycerol 1.5\%, sucrose $1.5 \%$, peptone $0.6 \%$, yeast extract $0.15 \%, \mathrm{NaCl} 3.0 \%$, $\mathrm{KH}_{2} \mathrm{PO}_{4} 0.06 \%, \mathrm{MgSO}_{4} .7 \mathrm{H}_{2} \mathrm{O} 0.5 \%, \mathrm{CuSO}_{4} .5 \mathrm{H}_{2} \mathrm{O} 0.0001 \%$ and $\mathrm{FeSO}_{4} .7 \mathrm{H}_{2} \mathrm{O} 0.0003 \%$; II) Vogel's medium consisted of dextrose $2.0 \%$ and Vogel's solution 2.0\% (21); III) Czapek's medium consisted of sucrose $3.0 \%, \mathrm{NaNO}_{3} 0.2 \%, \mathrm{~K}_{2} \mathrm{HPO}_{4} 0.05 \%, \mathrm{MgSO}_{4}$. $7 \mathrm{H}_{2} \mathrm{O} 0.05 \%, \mathrm{KCl} 0.05 \%$ and $\mathrm{FeSO}_{4} .7 \mathrm{H}_{2} \mathrm{O} 0.001 \%$ (1). The $\mathrm{pH}$ values of the media for the different experiments were set at 5.5, 6.0 and 7.5 at the beginning of fermentation, and the fungus cultures were incubated at 30,37 and $40^{\circ} \mathrm{C}$ at $120 \mathrm{rpm}$ for 144 , 168 and 192 hours.

\section{Extraction of metabolites}

Each culture broth was separated from mycelium by filtration under vacuum and submitted to three times partition with chloroform. The resulting chloroform fractions were combined and concentrated under vacuum to eliminate the organic solvent. Then, the furnished dried crude extracts were assayed for antimicrobial activity, and submitted to HPLC analysis.

\section{Antimicrobial activity assay}

The antimicrobial activity of the crude extracts was evaluated by using bioautography assay. The crude extracts were dissolved $(30 \mathrm{mg} / \mathrm{mL})$ in ethyl acetate, from which $8 \mu \mathrm{L}$ were applied on silica gel $\mathrm{G}_{60} \mathrm{~F}_{254}$ thin layer chromatography plates. The chromatograms were developed in chloroform/ methanol $(93: 7, \mathrm{v} / \mathrm{v})$ as mobile phase. After elution, the plates were carefully dried for complete removal of the solvents. A suspension of Kocuria rhizophila was prepared in saline solution by comparison with the 0.5 McFarland standard. Afterwards, the suspension was diluted $(2 \%)$ in antibiotic $\mathrm{N}^{\mathrm{o}} 1$ agar medium and distributed over the plates. Gentamicin discs were used as positive control. The thin layer chromatography plates were incubated overnight at $37^{\circ} \mathrm{C}$ in a humid chamber. Subsequently, the plates were overlaid with a solution of 2,3,5-triphenyltetrazolium chloride $(0.5 \%, \mathrm{p} / \mathrm{v})$, and the growth inhibition was observed as clear zones on the chromatograms (9).

\section{HPLC analysis}

Instrumentations consisted of a Shimadzu (SCL-10Avp, Japan) multisolvent delivery system, Shimadzu SPD-M10Avp Photodiode Array Detector, and an Intel Celeron computer for analytical system control, data collection and processing. Analytical chromatography of both the crude extracts obtained from the cultures and the unfermented media extracts was carried out using linear gradient (methanol-water 50\% to methanol $100 \%$ within $20 \mathrm{~min}$ ). ACLC-ODS (M) $-4.6 \times 250 \mathrm{~mm}$ Shimadzu column was used at a flow rate of $1.0 \mathrm{~mL} / \mathrm{min}$. The spectral data were collected within 20 min over the $200-400 \mathrm{~nm}$ range of the absorption spectrum, and the chromatograms were analyzed and plotted at $215 \mathrm{~nm}$.

\section{RESULTS AND DISCUSSION}

Four parameters were evaluated with regard to antimicrobial activity production by A. fumigatus: medium culture, $\mathrm{pH}$, temperature and time of fermentation. The ranges of the variables were selected based on prior biological knowledge as followed: many fungi show broad $\mathrm{pH}$ optima from 5.5 to 7.5 , but the enzymes needed in many natural environments often have specific $\mathrm{pH}$ optima and function over a quite narrow $\mathrm{pH}$ range (6). Therefore, the $\mathrm{pH}$ of 6.0 was selected. Moreover, the temperature of incubation may affect the metabolic pattern and nutritional requirements. Then, the useful range of temperature for the optimum enzyme function is usually quite narrow. In this sense, it is known that A. fumigatus has a good growth temperature at $40^{\circ} \mathrm{C}$. However, the temperature of $30^{\circ} \mathrm{C}$ was selected considering that, in some cases, the optimal temperature for growth is not the same for metabolite formation (7), and the temperature of $37^{\circ} \mathrm{C}$ was selected considering that pathogens generally grow well at this temperature. In addition, the biosynthesis of active compounds in fermentative cultures by microorganisms is directly related to the incubation time. In the present study, compounds with significant antimicrobial activity were detected after 144 hours and before 216 hours.

The use of different parameters led to changes in the antimicrobial activity of the A. fumigatus obtained extracts, even by using the same culture medium (Table 1). The obtained extracts from the fungus cultures displayed different TLC profiles 
Table 1. The inhibition of Kocuria rhizophila growth by different extracts of A. fumigatus cultures developed in Jackson's medium, Vogel's medium and Czapek's medium by varying the parameters of $\mathrm{pH}$, temperature and time of fermentation.

\begin{tabular}{|c|c|c|c|c|c|}
\hline \multirow[t]{2}{*}{$\mathrm{pH}$} & \multirow{2}{*}{$\begin{array}{l}\text { Temperature } \\
\quad\left({ }^{\circ} \mathrm{C}\right)\end{array}$} & \multirow{2}{*}{$\begin{array}{c}\text { Time of } \\
\text { fermentation (hours) }\end{array}$} & \multicolumn{3}{|c|}{ Inhibition spots (Rf values) } \\
\hline & & & Jackson's medium & Vogel's medium & Czapek's medium \\
\hline 5.5 & 30 & 144 & $0.29 ; 0.47 ; 0.66$ & $0.05 ; 0.50$ & $0.04 ; 0.32 ; 0.41$ \\
\hline 5.5 & 30 & 168 & $0.29 ; 0.47 ; 0.66$ & $0.05 ; 0.48$ & $0.04 ; 0.32 ; 0.44 ; 0.70 ; 0.91$ \\
\hline 5.5 & 30 & 192 & $0.47 ; 0.66$ & $0.26 ; 0.48$ & $0.04 ; 0.38 ; 0.50 ; 0.68$ \\
\hline 5.5 & 37 & 144 & $0.38 ; 0.56$ & $0.09 ; 0.48$ & 0.34 \\
\hline 5.5 & 37 & 168 & $0.29 ; 0.38 ; 0.56$ & $0.09 ; 0.48$ & $0.34 ; 0.50$ \\
\hline 5.5 & 37 & 192 & $0.29 ; 0.38 ; 0.72$ & $0.30 ; 0.48$ & 0.63 \\
\hline 5.5 & 40 & 144 & $0.03 ; 0.21 ; 0.29 ; 0.36 ; 0.45$ & $0.01 ; 0.45$ & $0.04 ; 0.32 ; 0.39$ \\
\hline 5.5 & 40 & 168 & $0.21 ; 0.45 ; 0.59$ & $0.01 ; 0.40$ & $0.04 ; 0.32 ; 0.45$ \\
\hline 5.5 & 40 & 192 & $0.45 ; 0.59$ & $0.01 ; 0.30$ & $0.04 ; 0.32$ \\
\hline 6.0 & 30 & 144 & $0.17 ; 0.32 ; 0.42 ; 0.56$ & $0.03 ; 0.37$ & $0.04 ; 0.21 ; 0.28 ; 0.32 ; 0.46$ \\
\hline 6.0 & 30 & 168 & $0.32 ; 0.42 ; 0.56$ & $0.03 ; 0.37$ & $0.04 ; 0.36 ; 0.51 ; 0.66$ \\
\hline 6.0 & 30 & 192 & $0.32 ; 0.42 ; 0.56$ & $0.08 ; 0.48$ & $0.04 ; 0.30 ; 0.48 ; 0.60$ \\
\hline 6.0 & 37 & 144 & $0.40 ; 0.70$ & $0.04 ; 0.31$ & 0.32 \\
\hline 6.0 & 37 & 168 & 0.24 & $0.25 ; 0.31$ & $0.07 ; 0.26 ; 0.32$ \\
\hline 6.0 & 37 & 192 & 0.24 & $0.25 ; 0.31$ & $0.07 ; 0.45 ; 0.69$ \\
\hline 6.0 & 40 & 144 & $\begin{array}{l}\text { Overlapping inhibition zones } \\
\qquad(0.09 \text { to } 0.65)\end{array}$ & $0.08 ; 0.35$ & $0.32 ; 0.41$ \\
\hline 6.0 & 40 & 168 & $0.37 ; 0.65$ & $0.08 ; 0.35$ & $0.04 ; 0.20$ \\
\hline 6.0 & 40 & 192 & 0.37 & $0.08 ; 0.48$ & $0.04 ; 0.30$ \\
\hline 7.5 & 30 & 144 & $0.39 ; 0.60$ & 0.68 & $0.31 ; 0.36$ \\
\hline 7.5 & 30 & 168 & $0.39 ; 0.60$ & $0.07 ; 0.58$ & 0.31 \\
\hline 7.5 & 30 & 192 & $0.39 ; 0.60$ & $0.07 ; 0.58$ & 0.31 \\
\hline 7.5 & 37 & 144 & $0.20 ; 0.42$ & 0.11 & $0.04 ; 0.22 ; 0.32$ \\
\hline 7.5 & 37 & 168 & 0.42 & $0.11 ; 0.30$ & $0.32 ; 0.42 ; 0.52$ \\
\hline 7.5 & 37 & 192 & 0.42 & $0.11 ; 0.61$ & 0.52 \\
\hline 7.5 & 40 & 144 & $0.15 ; 0.22 ; 0.30 ; 0.53$ & 0.04 & $0.03 ; 0.16 ; 0.28 ; 0.35 ; 0.47 ; 0.62$ \\
\hline 7.5 & 40 & 168 & $0.05 ; 0.15 ; 0.30$ & 0.24 & $0.03 ; 0.23 ; 0.35 ; 0.52$ \\
\hline 7.5 & 40 & 192 & $0.30 ; 0.53 ; 0.60$ & $0.24 ; 0.61$ & $0.03 ; 0.35 ; 0.52$ \\
\hline
\end{tabular}

and produced, at least, one inhibition zone in the bioautography assays. Control extracts from non-inoculated media run in parallel showed no activity.

The Rf values of the inhibiting components of the Jackson's medium chloroform extracts ranged from 0.03 to 0.72 . The obtained extract from the culture developed in Jackson's medium, initial $\mathrm{pH}$ of 6.0 and incubation at $40^{\circ} \mathrm{C}$ for 144 hours, exhibited overlapping inhibition zones in the range of Rf 0.09 to 0.65 . A smaller number of active compounds were produced at the same $\mathrm{pH}$ and temperature, by incubating the culture for 168 and 192 hours. Nevertheless, the obtained extracts from the cultures incubated longer than 144 hours at $37^{\circ} \mathrm{C}$, initial $\mathrm{pH} 5.5$, showed a larger number of active compounds than the cultures incubated for 144 hours at the same conditions. It should be pointed out that all the evaluated parameters played an important role on active metabolite production.

With regard to Vogel's medium, the inhibition zones of the crude chloroform extracts, displayed in bioautography, appeared within $\mathrm{Rf}$ values of 0.01 to 0.61 . However, the obtained extracts by developing the fungus culture in Vogel's medium furnished the smallest number of active compounds. The composition of the culture medium has an important role on secondary metabolite production by microorganisms. Glucose, which is an excellent carbon source for cell growth, has influenced the production of several antibiotics (15). In addition, either the presence or absence, as well as the difference in concentrations of media components (peptones, yeast extract and vitamins) may lead to the biosynthesis of different compounds (11). 
N.A.J.C. Furtado et al.

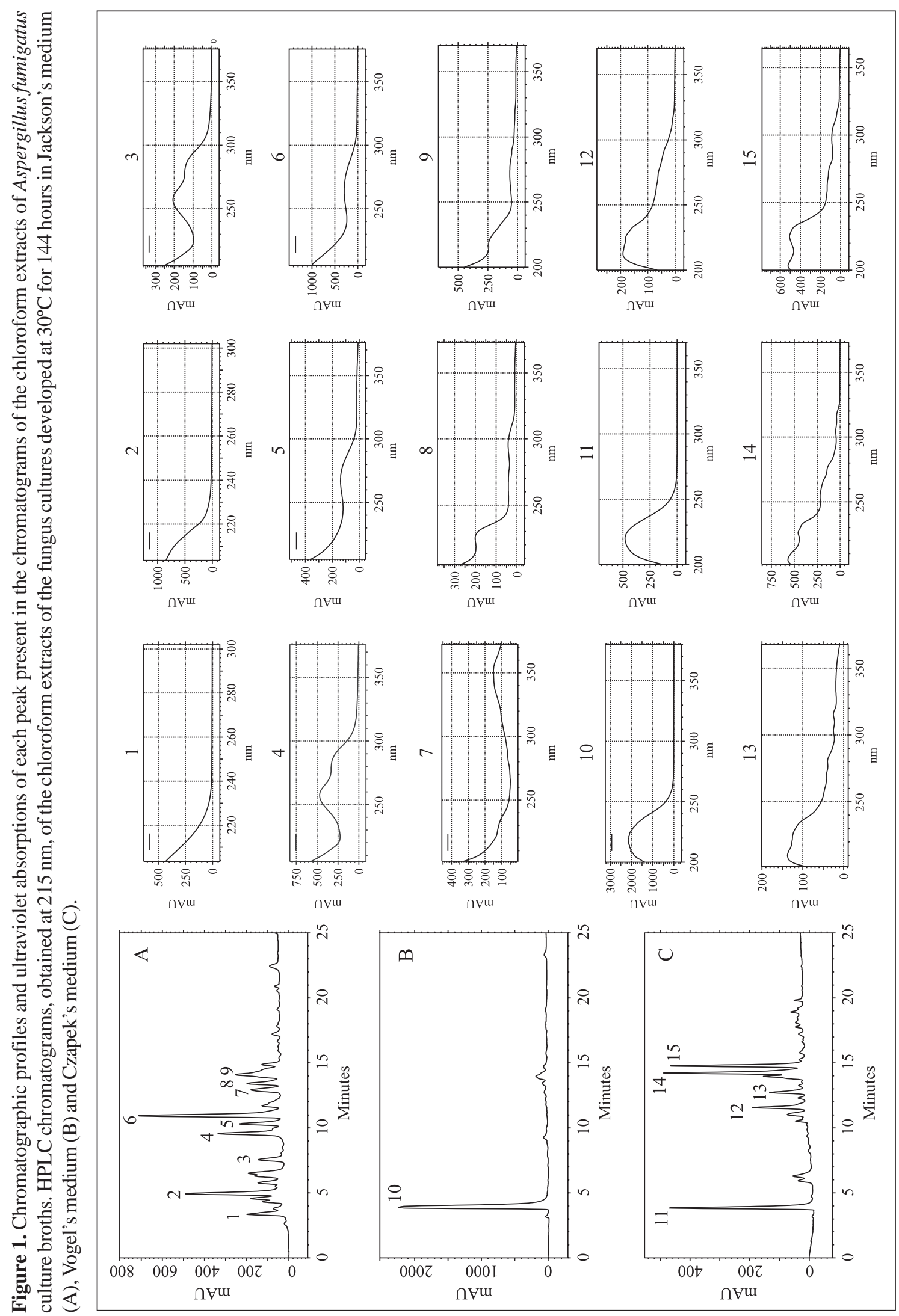


The bioautography assays of the chloroform extracts from Czapek's medium cultures displayed inhibition zones within Rf values of 0.03 to 0.91 . A larger number of active compounds were produced by the fungus culture starting at $7.5 \mathrm{pH}$ and incubated at $40^{\circ} \mathrm{C}$ for 144 hours.

The analyses of the HPLC profiles of the obtained extracts allowed to infer that A. fumigatus secondary metabolites production could be affected by modifying any of the undertaken parameters, mainly by using different media culture (Fig. 1). The chromatograms were plotted at $215 \mathrm{~nm}$ because it is commonly accepted that most of the natural secondary metabolites present $210-215 \mathrm{~nm}$ absorption and that many primary metabolites would be subtracted as components of the uninoculated media (19). The peaks present in the chromatograms of the chloroform extracts of Aspergillus fumigatus culture broths were not detected in the HPLC chromatographic profiles of the unfermented media extracts.

Depending on the environmental conditions, the fungal producers may be capable of changing the nature of the end synthesized products, and a large amount of bioactive compounds may be found after optimization of both growth and production conditions. In previous investigations it was found that the addition of a pool of bacteria to the A. fumigatus culture promoted the production of different metabolites (8).

The high genetic variability found in the strains of $A$. fumigatus might lead to novel metabolites with potential for the development of novel antibiotics. The Brazilian strain of $A$. fumigatus showed an inherent ability to produce antimicrobial activity, especially by cultivation in Jackson's medium, initial $\mathrm{pH}$ of 6.0 and incubation at $40^{\circ} \mathrm{C}$ for 144 hours.

\section{ACKNOWLEDGEMENTS}

We are grateful to "Fundação de Amparo a Pesquisa do Estado de São Paulo (FAPESP)" Brazil for financial support (proc. 99/09850-8) and to Dr. Suraia Said for providing the strain of A. fumigatus.

\section{RESUMO}

\section{O potencial de uma cepa brasileira de Aspergillus fumigatus para produzir metabólitos secundários antimicrobianos}

Em estudos desenvolvidos para encontrar produtos naturais biologicamente ativos provenientes de fungos, uma cepa de Aspergillus fumigatus foi avaliada para a produção de atividade antimicrobiana. Quatro parâmetros, consistindo de meio de cultura, $\mathrm{pH}$, temperatura e tempo de fermentação, foram investigados. Os extratos obtidos das culturas do fungo apresentaram perfis cromatográficos diferentes e produziram, ao menos, uma zona de inibição quando avaliados por bioautografia. Zonas de inibição sobrepostas na faixa de Rf 0.09 a 0.65 , contra Kocuria rhizophila, foram detectadas na bioautografia do extrato clorofórmico obtido da cultura desenvolvida no meio de Jackson, pH inicial 6,0 e incubação a $40^{\circ} \mathrm{C}$ por 144 horas. Entretanto, os extratos obtidos por desenvolver a cultura do fungo no meio de Vogel forneceram o menor número de compostos ativos. Os perfis cromatográficos obtidos dos extratos das culturas do fungo por cromatografia líquida de alta eficiência com detector de arranjo de diodos foram distintos, permitindo inferir que a produção de metabólitos secundários por Aspergillus fumigatus pode ser afetada pela modificação dos parâmetros investigados. Deve ser ressaltado que uma notável diferença nos perfis cromatográficos obtidos por CLAE foi observada por utilizar diferentes meios de cultura.

Palavras-chave: atividade antimicrobiana, Aspergillus fumigatus, bioautografia, condições de fermentação

\section{REFERENCES}

1. Atlas, R.M. Handbook of microbiological media. CRC Press, Boca Raton, 1995, p.280.

2. Cui, C.B.; Kakeya, H.; Osada, H. Novel mammalian cell cycle inhibitors, cyclotryprostatins A-D, produced by Aspergillus fumigatus, which inhibit mammalian cell cycle at G2/M phase. Tetrahedron, 53, 59-72, 1997.

3. Czarnik, A.W. Guest editorial. Acc. Chem. Res., 29, 112-113, 1996.

4. Debeaupuis, J.P.; Sarfati, J.; Chazalet, V.; Latgé, J.P. Genetic diversity among clinical and environmental isolates of Aspergillus fumigatus. Infect. Immun., 65, 3080-3085, 1997.

5. Demain, A.L. Pharmaceutically active secondary metabolites of microorganisms. Appl. Microbiol. Biotechnol., 52, 455-463, 1999.

6. Ellaiah, P.; Srinivasulu, B.; Adinarayana, K. Optimisation studies on neomycin production by a mutant strain of Streptomyces marinensis in solid state fermentation. Process Biochem., 39, 529 534, 2004.

7. Finkelstein, D.B.; Ball, C. Biotechnology of Filamentous Fungi: technology and products. Butterworth-Heinemann, Washington, 1992, 520p.

8. Furtado, N.A.J.C.; Said, S.; Ito, I.Y.; Bastos, J.K. The antimicrobial activity of Aspergillus fumigatus is enhanced by a pool of bacteria. Microbiol. Res., 157, 207-211, 2002.

9. Hamburger, M.O.; Cordell, G.A. A direct bioautographic TLC assay for compounds possessing antibacterial activity. J. Nat. Prod., 50, 19-22, 1987.

10. Jackson, M.; Karwoswsky, J.P.; Humphrey, P.E.; Kohl, W.L.; Barlow, G.J.; Tanaka, S.K. Calbistrins, novel antifungal agents produced by Penicillium restrictum. J. Antibiot., 46, 34-38, 1993.

11. Knight, V.; Sanglier, J.J.; DiTullio, D.; Braccili, S.; Bonner, P.; Waters, J.; Hughes, D.; Zhang. L. Diversifying microbial natural products for drug discovery. Appl. Microbiol. Biotechnol., 62, 446-458, 2003.

12. Latgé, J.P. The pathobiology of Aspergillus fumigatus. Trends Microbiol., 9, 382-389, 2001.

13. Newman, D.J.; Gragg, G.M.; Snader, K.M. Natural products as sources of new drugs over the period 1981-2002. J. Nat. Prod., 66, 1022 1037, 2003

14. Pfefferle, C.; Theobald, U.; Gürtler, H.; Fiedler, H.P. Improved secondary metabolite production in the genus Streptosporangium by optimization of the fermentation conditions. J. Biotechnol., 80 , 135-142, 2000. 
15. Sanchez, S.; Demain, A.L. Metabolic regulation of fermentation processes. Enzyme Microb. Technol., 31, 895-906, 2002.

16. Schmid, I.; Sattler, I.; Grabley, S.; Thiericke, R. Natural products in high throughput screening: automated high-quality sample preparation. J. Biomol. Screen., 4, 15-25, 1999.

17. Son, K.H.; Kim, Y.K.; Lee, H.W.; Lee, W.S.; Kim, S.U.; Jeong, T.S.; Kwon, B.M.; Bok, S.H. Amplification of farnesyl protein transferase inhibitory activity from Aspergillus fumigatus F93 by PlackettBurman design. Biotechnol. Lett., 18, 1297-1300, 1996.

18. Symoens, F.; Bertout, S.; Piens, M.A.; Burnod, J.; Renaud, F.; Nolard, N.; Chapuis, F.; Grillot, R.; EBGA Network A longitudinal study of lung transplant recipients infected with Aspergillus: genetic polymorphism of A. fumigatus. J. Heart Lung Transplant., 20, 970978, 2000.

19. Tormo, J.R.; García, J.B.; DeAntonio, M.; Feliz, J.; Mira, A.; Díez, M.T.; Hernández, P.; Peláez, F. A method for the selection of production media for actinomycete strains based on their metabolite HPLC profiles. J. Ind. Microbiol. Biotechnol., 30, 582-588, 2003.

20. Varga, J.; Tóth, B. Genetic variability and reproductive mode of Aspergillus fumigatus. Infect. Genet. Evol., 3, 3-17, 2003.

21. Vogel, H.J. A convenient medium for Neurospora (medium N). Microb. Gen. Bull., 13, 42, 1956. 